\title{
Cow-Related Risk Factors for Milk Leakage
}

\author{
I. C. Klaas, ${ }^{1,2}$ C. Enevoldsen, ${ }^{2}$ A. K. Ersbøll, ${ }^{3}$ and U. Tölle ${ }^{4}$ \\ ${ }^{1}$ Danish Institute of Agricultural Sciences, \\ Department of Animal Health and Welfare, PO Box 50, DK-8830 Tjele, Denmark \\ ${ }^{2}$ Department of Clinical Studies, Large Animal Medicine, and \\ ${ }^{3}$ Department of Animal Science and Animal Health, Division of Epidemiology, \\ The Royal Veterinary and Agricultural University, DK-1870 Frederiksberg C, Denmark \\ ${ }^{4}$ Landeskontrollverband Schleswig-Holstein e.V., D-24106 Kiel, Germany
}

\begin{abstract}
Milk leakage in dairy cows is a symptom of impaired teat sphincter function. Milk leakage is related to an increased risk of mastitis in heifers and cows, and causes hygiene problems. The aim of our study was to assess whether teat shape, condition of teat orifice, and peak milk flow rate are risk factors for milk leakage. We conducted a longitudinal observational study in 15 German dairy farms in which cows were maintained in loose housing. The farms were visited monthly at 2 consecutive milkings. During the evening milking, milk flow curves were measured with the LactoCorder. Milk leakage was recorded during the subsequent morning milking, when cows entered the milking parlor. Immediately after detachment of the milking cluster, teat shape, teat end shape, and condition of the teat orifice of cows were assessed between 9 and $100 \mathrm{~d}$ in milk (DIM) and during late lactation ( $>250$ DIM). Data from 1600 cows were analyzed. Milk leakage was treated as the binary response variable in a logistic regression model with herd as a random effect. Primiparous cows with high peak milk flow and teat canal protrusion were at greater risk of milk leakage. High peak milk flow rate, short teats, teat canal protrusion, inverted teat ends, and early lactation increased the risk of milk leakage in multiparous cows. Random herd effects accounted for only $10 \%$ of the total variation, indicating that the impact of management or other herd-level factors on the occurrence of milk leakage is virtually negligible for practical purposes.
\end{abstract}

(Key words: milk leakage, teat shape, peak milk flow)

Abbreviation key: DevMilk = deviation from the population mean milk yield adjusted for stage of lactation and parity, DevPMF = deviation from the population mean peak milk flow adjusted for stage of lactation and parity, MeanResMilk = mean residual of observed expected milk yield.

Received November 14, 2003.

Accepted August 11, 2004.

Corresponding author: Ilka C. Klaas; e-mail: ilka.klaas@agrsci.dk.

\section{INTRODUCTION}

Milk leakage is a condition in which milk loss occurs through the teat canal in absence of milking. Frequency of cows leaking milk differs among farms and ranges between 0 and $36 \%$ of cows within a farm (Schukken et al., 1990). An increased risk for milk leakage was reported in cows milked by automatic milking systems (Persson Waller et al., 2003). Results from field studies have shown that in herds in which cows leak milk, the risk for clinical Escherichia coli mastitis increases (Schukken et al., 1991; Elbers et al., 1998). On an individual cow level, milk leakage increases the risk for clinical mastitis in periparturient heifers (Waage et al., 2001). Milk leakage was a risk factor for mastitis in these studies. From experimental studies it is known that milk leakage can be elicited and enhanced by several means. Milk leakage was observed after i.v. infusion of oxytocin that led to active descent of alveolar milk and increased intramammary pressure (Vandeputte-Van Messom et al., 1984). Further, milk leakage can be enhanced by $\beta$-receptor agonists (Baxter et al., 1950) or $\alpha$-blocking agents (Vandeputte-Van Messom et al., 1984). High-yielding and easy milking cows are reported to be at greater risk for milk leakage (Wendt et al., 1994). Most of our understanding about causes for milk leakage is derived from experimental studies under controlled conditions using small numbers of cows.

The aim of our study was to identify risk factors for milk leakage on an individual cow level and to examine the relationships between milk yield, peak milk flow, teat shape, and teat orifice condition under field conditions. Further, we wanted to estimate the variance components resulting from herd and individual cows.

\section{MATERIALS AND METHODS}

\section{The Herds}

A longitudinal observational study was conducted in 15 commercial dairy farms in Schleswig-Holstein, Germany. The farms were enrolled from January 1997 to 
Table 1. Characteristics of 15 dairy herds participating in a study on risk factors for milk leakage.

\begin{tabular}{|c|c|c|c|c|c|c|}
\hline Herd & Cow-years & Breed $^{1}$ & $\begin{array}{l}\text { ECM, }{ }^{2} \\
305-d\end{array}$ & $\begin{array}{l}\text { SCC }(\times \\
1000 / \mathrm{mL})\end{array}$ & No. of cows & $\begin{array}{l}\% \text { of cows } \\
\text { with milk } \\
\text { leakage }\end{array}$ \\
\hline 1 & 46 & $\mathrm{RH},(\mathrm{HF})$ & 7895 & 81 & 57 & 5.3 \\
\hline 2 & 92 & HF, Angeln cows (crossings) & 7793 & 148 & 105 & 8.6 \\
\hline 3 & 85 & $\mathrm{HF}, \mathrm{RH}$ & 8895 & 172 & 121 & 2.4 \\
\hline 4 & 70 & $\mathrm{HF}$ & 8165 & 179 & 107 & 5.6 \\
\hline 5 & 63 & $\mathrm{RH}$ & 7710 & 145 & 90 & 8.7 \\
\hline 6 & 70 & $\mathrm{HF}$ & 9124 & 160 & 97 & 7.2 \\
\hline 7 & 110 & $\mathrm{RH}(\mathrm{HF})$ & 5671 & 247 & 161 & 5.6 \\
\hline 8 & 99 & RH (crossings) & 6906 & 344 & 133 & 3.4 \\
\hline 9 & 66 & HF (crossings) & 5287 & 187 & 73 & 12.3 \\
\hline 10 & 100 & Angeln cows & 8566 & 143 & 146 & 1.4 \\
\hline 11 & 64 & HF (crossings) & 9809 & 150 & 78 & 6.4 \\
\hline 12 & 70 & $\mathrm{HF}$ & 8882 & 139 & 106 & 6.6 \\
\hline 13 & 53 & $\mathrm{RH}$ & 6245 & 253 & 86 & 1.2 \\
\hline 14 & 56 & Angeln cows & 8576 & 187 & 84 & 6.0 \\
\hline 15 & 87 & HF (crossings) & 6778 & 140 & 111 & 3.6 \\
\hline
\end{tabular}

${ }^{1}$ Dominant breed in herd, minor breeds in parentheses; HF $=$ German Holstein-Friesian, $\mathrm{RH}=$ German Red Holstein, Angeln cows = local red milking breed, crossings = parents of different milking breeds.

${ }^{2} \mathrm{ECM}=$ Energy-corrected milk yield.

December 1998 with the aim to improve the udder health (Klaas, 2000). To be enrolled, farms had to meet the following criteria: 1) regular milk recording occurred; 2) farmers were advised by agricultural advisory services; and 3) milking machines were checked once annually. Thirteen farms had herringbone-type milking parlors, and 2 farms had tandem parlors. Table 1 describes herd characteristics. All herds were housed in free-stall barns with slatted floors, and grazing occurred during summer (April to October).

\section{Data Collection}

Data were collected at monthly farm visits except during July 1997 and 1998, during which time no milk recording was performed. During the evening milking of $d 1$, milk flow curves were measured with the LactoCorder (Werkzeug- und Maschinenbau Berneck AG, Baldach, Switzerland). From January until October 1997, the LactoCorder milk recording occurred in addition to the milk test day and was carried out on the day after test day. From November 1997 until December 1998, the LactoCorder was officially used on milk test-days in the study farms. The LactoCorder measured milk flow throughout the whole milking, as well as milk yield. Milk flow characteristics were measured every $0.7 \mathrm{~s}$ and saved with value changes or at intervals of $2.8 \mathrm{~s}$. Peak milk flow was defined as the maximum milk flow within 8 measurements $(22.4 \mathrm{~s})$ and expressed in kilograms/minute. Maximum milk flow is usually measured during the plateau phase of the milk flow curve.

Cows were examined clinically at the morning milking of $d$ 2. Milk leakage was recorded in the milking parlor while the cows entered the milking parlor from the holding area. Milk leakage was recorded for each quarter and was defined as milk dropping or flowing from the teat. Immediately after detachment of the milking cluster, udders and teats of all cows from 9 to 100 DIM and during late lactation (>250 DIM) were examined (visual inspection and palpation). Absence or presence of edema was recorded. Classification of teat and teat-end shape was based on Rosenberger (1979). Teat orifice was classified as normal, teat canal protrusion, white smooth callosity ring, or rough callosity ring. Definitions of teat characteristics are summarized in Table 2. Teat characteristics were recorded for each quarter. Udder size was classified for each cow by assessing the height of the ventral floor (teats not included) relative to the hocks (Table 2).

\section{Data Editing and Analyses}

Data were checked for unlikely values. Observations from 49 cows with less than $2 \mathrm{~kg}$ of milk were excluded because the recorded milk flow curves were not interpretable. Two measurements with a peak milk flow greater than $11 \mathrm{~kg} / \mathrm{min}$ and milk yield during one milking of greater than $33 \mathrm{~kg}$ were excluded because they were regarded as technical errors. Typically, these values indicate that the LactoCorder was in cleaning rather than recording mode. In 20 quarters from 20 cows, the teat orifice showed an acute pathological lesion or scar tissue. These quarters were excluded because of low prevalence in the final results and because the injured teats did not represent genuine teat characteristics of the cow in question. Further, 105 quarters of 105 observations from 65 cows were excluded because 
Table 2. Definition of teat characteristics and udder size for all cows with or without milk leakage included in the analysis (based on Rosenberger, 1979).

\begin{tabular}{lll}
\hline Variable & Levels & Definition \\
\hline Teat shape & Short and thin & Length $<4.5 \mathrm{~cm}$ and diameter $<2 \mathrm{~cm}$ \\
& Short and thick & Length $<4.5 \mathrm{~cm}$ and diameter $\geq 2 \mathrm{~cm}$ \\
& Normal & Length 4.5 to $6.5 \mathrm{~cm}$, diameter 2 to $3 \mathrm{~cm}$ \\
& Conical & Diameter teat end $<$ diameter of teat base \\
Teat end shape & Thick & Length $>6.5 \mathrm{~cm}$, diameter $>3 \mathrm{~cm}$ \\
& Inverted & Slightly or clearly inverted \\
& Flat & Flat or slightly plate-like \\
Teat orifice & Nound & Slightly or clearly pointed \\
& Protrusion & Intact orifice, no lesions \\
& White callosity ring & Protrusion of teat canal like a thin pink ring, \\
& on black teats thin greyish ring \\
& Wough callosity ring & White thick ring with smooth surface \\
& Acute lesion/scar tissue & Anite thick ring with cracked surface \\
& Tiny & Shalf of the distance between hock \\
Udder size & and fold of the flank \\
& Small & above hock level, but $\geq$ half of the distance \\
& Normal & between hock and fold of the flank \\
& Deep & Ending at hock level \\
& & Below hock level \\
\hline
\end{tabular}

they did not yield milk. After editing, 2815 records from 1557 cows with 11,187 quarters were analyzed in the initial model. In only $27 \%$ of the cows was more than one measurement available. Therefore, one observation per cow was analyzed. When more than one measurement per cow was available, one observation was randomly chosen.

Milk leakage was treated as a binary response variable in a random effect logistic regression model using the GLIMMIX macro of SAS (Littell et al., 1996). The initial hierarchical structure was: herds, cows within herd, and quarters within cow. These models resulted in serious underdispersion. Dispersion parameters for the different models were in the interval 0.6 to 0.13 . The dispersion parameter allows the residual variances to deviate from their expected values. A value $>1$ indicates more variation than expected by chance and is referred to as overdispersion. Similarly, a value $<1$ indicates less than expected variation and is referred to as underdispersion (Brown and Prescott, 1999). A solution to this problem could have been to aggregate quarter observations for each cow, because only 9 of 131 cows having milk leakage had $<4$ affected quarters. Because the levels in the categorical variables could not be regarded as linear, an aggregation on a cow level as a cowmedian or cow-mean was not reasonable. Therefore, one quarter per cow was selected randomly. This approach still permitted evaluation of quarter-level risk factors. The model building process continued with herd as a random effect.

To screen for multicollinearity, all variables were checked using Pearson's correlation coefficients (continuous variables only) or Spearman's rank correlation coefficients. We defined the occurrence of multicollinearity at coefficients $>0.5$. According to this definition, multicollinearity was present between peak milk flow and milk yield, milk yield and parity, milk yield and stage of lactation, and parity and teat shape.

To control for multicollinearity, milk yield and peak milk flow were corrected for parity and stage of lactation. Instead of milk yield measured during the LactoCorder recordings, the energy-corrected total milk yield on the official test-day was used to model lactation curves for all cows. By applying a piecewise-linear model, a lactation curve for 3 parity groups $(1,2$, and $>2)$ was fitted. The method was suggested by Enevoldsen et al. (2000) and applied by Nielsen et al. (2002). A cow's mean residual derived from the piecewise-linear model characterized milk yield as low, average, or high. Mean residuals (MeanResMilk) were checked for outliers (4 observations with $>4$ times the standard error were excluded) and normal distribution. As a continuous variable, MeanResMilk entered the random effect logistic regression model with milk leakage as the binary outcome. A second approach to test whether volume of milk affected the risk of milk leakage was to transform the milk yield in deviation from the mean milk yield (DevMilk) within stage of lactation (see Table 3 for grouping) and parity (grouped as 1, 2, and $>2$ ) across herds.

Deviation from mean peak milk flow (DevPMF) was the cow's deviation from the mean peak milk flow within the same stage of lactation and within the same parity across herds. To control the correlation between parity and teat shape, results from primiparous and multiparous cows were analyzed separately. 
Table 3. Descriptive statistics of analyzed categorical risk factors for milk leakage in primiparous and multiparous cows.

\begin{tabular}{|c|c|c|c|c|c|}
\hline \multirow[b]{2}{*}{ Variables } & \multirow[b]{2}{*}{ Levels } & \multicolumn{2}{|c|}{ Primiparous cows } & \multicolumn{2}{|c|}{ Multiparous cows } \\
\hline & & No. & $\begin{array}{l}\text { No. }(\%) \\
\text { with leakage }\end{array}$ & No. & $\begin{array}{l}\text { No. }(\%) \\
\text { with leakage }\end{array}$ \\
\hline \multirow[t]{4}{*}{ Stage of lactation } & 9 to $30^{1}$ & 150 & $14(9.3)$ & 250 & $21(8.4)$ \\
\hline & 31 to 60 & 251 & $16(6.3)$ & 312 & $10(3.2)$ \\
\hline & 61 to 100 & 123 & $5(4.1)$ & 171 & $11(6.4)$ \\
\hline & 250 to 305 & 95 & $3(3.2)$ & 205 & $3(1.5)$ \\
\hline \multirow[t]{5}{*}{ Teat shape } & Short and thin & 69 & $6(8.3)$ & 11 & $2(18.2)$ \\
\hline & Short and thick & 263 & $20(7.6)$ & 196 & $15(7.7)$ \\
\hline & Normal & 192 & $9(4.7)$ & 297 & $12(6.1)$ \\
\hline & Conical & 32 & $2(6.3)$ & 39 & $2(5.1)$ \\
\hline & Thick & 63 & $4(6.3)$ & 395 & $14(3.5)$ \\
\hline \multirow[t]{3}{*}{ Teat end shape } & Inverted & 36 & $1(2.8)$ & 40 & $4(11.1)$ \\
\hline & Flat & 159 & $12(7.5)$ & 207 & $17(8.2)$ \\
\hline & Round & 424 & $25(5.9)$ & 691 & $24(3.4)$ \\
\hline \multirow[t]{5}{*}{ Teat orifice } & Protrusion & 29 & $7(24.1)$ & 38 & $7(18.4)$ \\
\hline & Normal & 257 & $13(5.1)$ & 421 & $20(4.7)$ \\
\hline & White ring & 275 & $16(5.8)$ & 340 & $16(4.7)$ \\
\hline & Rough callosity & & & & \\
\hline & ring & 58 & $2(3.4)$ & 139 & $2(1.4)$ \\
\hline \multirow[t]{2}{*}{ Edema } & Yes & 83 & $8(9.6)$ & 47 & $3(6.4)$ \\
\hline & No & 536 & $30(5.6)$ & 891 & $42(4.7)$ \\
\hline \multirow[t]{4}{*}{ Udder size } & Tiny & 17 & $3(17.6)$ & 0 & 0 \\
\hline & Small & 532 & $31(5.8)$ & 255 & $14(5.5)$ \\
\hline & Normal & 70 & $4(5.7)$ & 613 & $26(4.2)$ \\
\hline & Deep udder & 0 & 0 & 70 & $5(7.1)$ \\
\hline \multirow[t]{4}{*}{ Breed } & Angeln cows ${ }^{2}$ & 100 & $5(5.0)$ & 135 & $2(1.5)$ \\
\hline & Crossings $^{3}$ & 15 & $1(6.7)$ & 19 & $1(5.3)$ \\
\hline & $\mathrm{RH}^{4}$ & 239 & $15(6.3)$ & 310 & $15(4.8)$ \\
\hline & $\mathrm{HF}^{5}$ & 265 & $17(6.4)$ & 474 & $27(4.0)$ \\
\hline \multirow[t]{6}{*}{ Year and season } & Jan-Apr 1997 & 53 & $4(7.6)$ & 105 & $4(3.8)$ \\
\hline & May-Sep 1997 & 84 & $6(7.1)$ & 228 & $11(4.8)$ \\
\hline & Oct-Dec 1997 & 118 & $10(8.5)$ & 153 & $5(3.3)$ \\
\hline & Jan-Apr 1998 & 90 & $7(7.8)$ & 156 & $10(6.4)$ \\
\hline & May-Sep 1998 & 128 & $4(3.1)$ & 177 & $4(2.3)$ \\
\hline & Oct-Dec 1998 & 146 & $7(4.8)$ & 119 & $11(9.2)$ \\
\hline Total & & 619 & $38(6.1)$ & 938 & $45(4.8)$ \\
\hline
\end{tabular}

${ }^{1}$ Days in milk.

${ }^{2}$ Local red milking breed.

${ }^{3}$ Parents of different milking breeds.

${ }^{4}$ German Red Holstein

${ }^{5}$ German Holstein-Friesian.

The model building process started with the baseline random intercept model to evaluate the random herd effect. Risk factors were first analyzed with univariable models, each one tested for its effect on the random herd effect. The final model was generated using stepwise backwards elimination. In each step, model quality was checked by the log-likelihood ratio test and by evaluation of Akaike's information criteria (Brown and Prescott, 1999). Coefficient estimates in different models were checked for changes indicating confounding or poor data quality. Risk factors tested in the initial model were DevPMF, MeanResMilk, DevMilk, udder edema, breed, teat orifice, teat shape, teat-end shape, udder size, season (January-April, May-September, October-December in 1997 and 1998), and DIM.

Continuous variables, peak milk flow, DevPMF, MeanResMilk, DevMilk, and DIM were checked for linear relationship with the outcome variable by testing the model with polynomials of different degrees. Furthermore, linearity was tested by transforming the continuous variables into categorical variables. Results indicated a linear relationship. No first-order interactions between continuous variables were found. Interactions between continuous variables and categorical variables were not significant. Models including interaction terms between teat-end shape, teat shape, and teat orifice did not converge.

The final model chosen for primiparous cows included DevPMF, MeanResMilk, teat orifice, and DIM as fixed effects and herd as a random effect. The final model for multiparous cows included DevPMF, MeanResMilk, teat orifice, teat shape, teat-end shape, quarter position of the randomly chosen udder quarter, and DIM as fixed 
Table 4. Peak milk flow, milk yield, and residuals estimated from the milk model in primiparous and multiparous cows with or without milk leakage.

\begin{tabular}{llcccc}
\hline & \multicolumn{2}{c}{ Primiparous cows } & & \multicolumn{2}{c}{ Multiparous cows } \\
\cline { 2 - 3 } \cline { 5 - 6 } Variables & Leakage & No leakage & & Leakage & No leakage \\
\cline { 2 - 3 } & & \multicolumn{3}{c}{ Mean (SD) } & \\
Peak milk flow, kg/min & $3.5(1.1)$ & $2.9(0.9)$ & & $4.1(1.1)$ & $3.5(1.1)$ \\
Milk yield, ${ }^{1} \mathrm{~kg}$ & $10.6(2.4)$ & $10.3(2.9)$ & & $14.2(4.1)$ & $13.0(4.7)$ \\
MeanResMilk, ${ }^{2} \mathrm{~kg}$ & $-0.78(4.36)$ & $-0.06(5.00)$ & & $-1.25(6.10)$ & $-0.20(6.04)$ \\
\hline
\end{tabular}

${ }^{1}$ From evening milking, LactoCorder recording.

${ }^{2}$ Mean residuals from milk model.

effects, and herd as a random effect. The random logistic regression model was as follows:

$$
\begin{gathered}
\text { Logit } \mathrm{P}(\text { milk leakage })_{\mathrm{ijkm}}= \\
\beta_{0}+\Sigma \beta_{\mathrm{i}} \mathrm{RF}_{\mathrm{i}}+\Sigma \beta_{\mathrm{jk}} \mathrm{FRF}_{\mathrm{jk}}+\mathrm{RH}_{\mathrm{m}}
\end{gathered}
$$

where $\mathrm{P}$ is the probability for milk leakage, $\beta_{0}=$ intercept, $\beta_{\mathrm{i}}=$ regression coefficient for the continuous risk factor $i, R F_{i}=$ value of risk factor $i, F R F$ is the fixed effect of the categorical risk factor $\mathrm{j}$ on level $\mathrm{k}$, and $\mathrm{RH}_{\mathrm{m}}=$ random herd effect for herd $\mathrm{m}$.

Variances in the models were measured on a logit scale, whereas the variance on residual level was measured on a binomial scale. Under the assumption that no extrabinomial variation is permitted, level 1 (cow) variance was constrained to be equal to 1 on the binomial scale. Estimates of the proportion of variation explained by herd were computed by assuming that level 1 variance on a logit scale was $\pi^{2} / 3$ (Dohoo et al., 2001).

\section{RESULTS}

Milk leakage was observed in 5.3\% of the cows, ranging from 1.2 to $12.3 \%$ among herds (Table 1). Tables 3 and 4 describe categorical and continuous risk factors analyzed in the random effect, logistic-regression model. Milk leakage was observed in $6.1 \%$ of the primiparous cows and in $4.8 \%$ of the multiparous cows. In the multiparous cows, the average peak milk flow decreased from $3.7 \mathrm{~kg} / \mathrm{min}$ during the first month of lactation to $3.0 \mathrm{~kg} / \mathrm{min}$ after 250 DIM.

\section{Primiparous Cows}

The most important risk factor in first-lactation cows was DevPMF. The larger the DevPMF, the greater the risk for milk leakage (Table 5). Further, cows having teat canal protrusions were at greater risk of milk leakage than those having normal teat orifices and all other orifice characteristics. Lower yielding cows and those

Table 5. Significant risk factors for milk leakage in primiparous cows $(n=619)$ in the final random effect logistic regression model. Estimated coefficients (b), standard errors for the estimates (SE), odds ratio (OR), $95 \%$ confidence interval (CI) for OR, and the overall significance level from $F$-test are given for each risk factor.

\begin{tabular}{lllllr}
\hline Risk factor/level & $\mathrm{b}$ & $\mathrm{SE}$ & OR & $95 \%$ CI for OR & $P$ \\
\hline Intercept $_{\text {DevPMF }}$ & -2.655 & 0.481 & & & $<0.001$ \\
MeanResMilk $^{2}$ & 0.755 & 0.192 & $2.12^{3}$ & 1.46 to 3.10 & $<0.001$ \\
DIM & -0.086 & 0.042 & $0.92^{4}$ & 0.85 to 1.00 & 0.041 \\
Teat orifice & -0.006 & 0.003 & $0.99^{5}$ & 0.99 to 1.00 & \\
Protrusion & & & & & 0.054 \\
White ring & $1.948^{\mathrm{a}}$ & 0.584 & 7.02 & 2.23 to 22.04 & 0.016 \\
Rough callosity ring & $0.257^{\mathrm{b}}$ & 0.405 & 1.29 & 0.59 to 2.86 & \\
Normal & $0.040^{\mathrm{b}}$ & 0.808 & 1.04 & 0.22 to 5.07 & \\
\hline
\end{tabular}

${ }^{\mathrm{a}, \mathrm{b}}$ Two levels for the same risk factor having different superscripts letters differ $(P<0.05$; pairwise comparison).

${ }^{1}$ DevPMF = Deviation from mean peak milk flow in $\mathrm{kg} / \mathrm{min}$ corrected for stage of lactation.

${ }^{2}$ MeanResMilk = Mean residual from milk model $(\mathrm{kg})$.

${ }^{3}$ For an increase in DevPMF of $1 \mathrm{~kg}$.

${ }^{4}$ For an increase in MeanResMilk of $1 \mathrm{~kg}$.

${ }^{5}$ For an increase in DIM of $1 \mathrm{~d}$. 
Table 6. Significant risk factors for milk leakage in multiparous cows $(n=938)$ in the final random effect logistic regression model. Estimated coefficient (b), standard error (SE) for the coefficient, odds ratio (OR), 95\% confidence interval (CI) for OR, and significance level from $F$-test are given for each risk factor.

\begin{tabular}{|c|c|c|c|c|c|c|}
\hline Risk factor & Level & $\mathrm{b}$ & SE & OR & $95 \% \mathrm{CI}$ for OR & $P$ \\
\hline Intercept & & -2.884 & 0.478 & & & $<0.001$ \\
\hline $\operatorname{DevPMF}^{1}$ & & 0.448 & 0.135 & $1.57^{2}$ & 1.20 to 2.04 & 0.001 \\
\hline DIM & & -0.005 & 0.002 & $0.99^{3}$ & 0.990 to 0.999 & 0.011 \\
\hline \multirow[t]{5}{*}{ Teat shape } & Short and thin & $2.520^{\mathrm{a}}$ & 0.843 & 12.43 & 2.38 to 64.88 & \multirow[t]{5}{*}{0.020} \\
\hline & Short and thick & $1.023^{\mathrm{a}}$ & 0.383 & 2.78 & 1.31 to 5.89 & \\
\hline & Normal & $0.436^{\mathrm{b}}$ & 0.390 & 1.55 & 0.72 to 3.32 & \\
\hline & Conical & $0.665^{\mathrm{ab}}$ & 0.733 & 1.94 & 0.46 to 8.18 & \\
\hline & Thick & $0^{\mathrm{ab}}$ & & 1 & & \\
\hline \multirow{3}{*}{ Teat end shape } & Inverted & $1.840^{\mathrm{a}}$ & 0.569 & 6.30 & 2.06 to 19.22 & \multirow{3}{*}{0.009} \\
\hline & Flat & $0.549^{b}$ & 0.311 & 1.73 & 0.94 to 3.18 & \\
\hline & Round & $0^{\mathrm{bc}}$ & & 1 & & \\
\hline \multirow[t]{4}{*}{ Teat orifice } & Protrusion & $1.991^{\mathrm{a}}$ & 0.483 & 7.32 & 2.83 to 18.88 & \multirow[t]{4}{*}{0.001} \\
\hline & White ring & $0.304^{\mathrm{b}}$ & 0.332 & 1.36 & 0.71 to 2.60 & \\
\hline & Rough callosity & $-0.502^{b}$ & 0.693 & 0.61 & 0.16 to 2.36 & \\
\hline & Normal & $0^{\mathrm{b}}$ & & 1 & & \\
\hline \multirow[t]{4}{*}{ Quarter position } & Right front & $-0.555^{\mathrm{ab}}$ & 0.404 & 0.57 & 0.26 to 1.27 & \multirow[t]{4}{*}{0.067} \\
\hline & Left front & $-0.209^{\mathrm{a}}$ & 0.368 & 0.81 & 0.39 to 1.67 & \\
\hline & Right rear & $-1.148^{\mathrm{b}}$ & 0.434 & 0.32 & 0.13 to 0.74 & \\
\hline & Left rear & $0^{\mathrm{a}}$ & & 1 & & \\
\hline
\end{tabular}

${ }^{\mathrm{a}, \mathrm{b}}$ Two levels for the same risk factor having different superscripts letters differ $(P<0.05$; pairwise comparison).

${ }^{1}$ Deviation from mean peak milk flow in $\mathrm{kg} / \mathrm{min}$ corrected for stage of lactation and parity.

${ }^{2}$ For an increase in DevPMF of $1 \mathrm{~kg}$.

${ }^{3}$ For an increase in DIM of $1 \mathrm{~d}$.

in early lactation were at slightly greater risk for milk leakage. Teat shape, teat-end shape, edema, quarter position, and breed did not alter risk for milk leakage in primiparous cows. Variation among cows within herd accounted for $89.2 \%$ of the total variation in the data.

\section{Multiparous Cows}

Multiparous cows having greater peak milk flow than average in the same parity and stage of lactation were at greater risk for milk leakage. The risk of milk leakage was greater at the beginning of lactation. Further, the risk for milk leakage was greater in cows having teat canal protrusions, inverted teat end shapes, and short teats (Table 6). Milk yield did not affect the risk for milk leakage in multiparous cows. The cow-level variance component was $89.6 \%$ (Table 7).

\section{DISCUSSION}

The proportion of observed cows with milk leakage was within the range of that reported by Schukken et al. (1991). In contrast to Schukken et al. (1991), we detected cows with milk leakage in all herds. When comparing studies, different methods of scoring of cows with milk leakage must be considered. Schukken et al. (1991) asked farmers to report the number of cows leaking milk between milkings. They detected a relationship between type of bedding and the occurrence of milk leakage and concluded that milk leakage is easier to detect on rubber mats than on other types of bedding. Sieber and Farnsworth (1981) detected $2.9 \%$ of teats leaking milk when observing cows during the early afternoon in the barn. We decided to measure milk leakage before milking (when cows entered the parlor), when the amount of milk stored in the udder

Table 7. Estimates of variance components (b) on logit scale, standard error (SE), significance level from Wald's test and proportion of the total variance explained at each level of the hierarchy in primiparous and multiparous cows.

\begin{tabular}{|c|c|c|c|c|c|c|c|c|}
\hline & \multicolumn{4}{|c|}{ Primiparous cows } & \multicolumn{4}{|c|}{ Multiparous cows } \\
\hline & $\mathrm{b}$ & $\mathrm{SE}$ & $P$ & $\begin{array}{l}\text { Proportion } \\
(\%)\end{array}$ & $\mathrm{b}$ & $\mathrm{SE}$ & $P$ & $\begin{array}{l}\text { Proportion } \\
(\%)\end{array}$ \\
\hline Herd & 0.40 & 0.34 & 0.14 & 10.8 & 0.38 & 0.28 & 0.092 & 10.4 \\
\hline Within-herd & 0.92 & 0.05 & $<0.001$ & 89.2 & 0.77 & 0.04 & $<0.001$ & 89.6 \\
\hline
\end{tabular}


and the resulting intramammary baseline pressure was assumed greatest. Our methodology was supported by reported high occurrences of milk leakage from cows housed in free-stall and tie-stall barns just before the morning milking (Persson Waller et al., 2003). To obtain uniform observations from clinical examinations, one person examined all cows during our study. Further, a detailed recording sheet was used with precise descriptions of the different levels within a category.

When analyzing udder-related risk factors, problems arise concerning the assessment of different quarters within a cow. In our study, the response variable (milk leakage), as we measured and defined it, was more likely to affect the whole cow than individual quarters. Of cows having teats leaking milk, only 9 showed leakage in less than 4 quarters. This may have been the main reason for underdispersion occurring in a hierarchical model in which all quarters were included as a random effect. When there are uniform effect categories, the dispersion parameter will be $<1$, and removing observations corresponding to the uniform effects is preferable (Brown and Prescott, 1999). Consequently, inclusion of the quarter level in the hierarchical model did not provide much additional information compared with the cow-level model with herd as a random effect. Furthermore, quarter position was insignificant as a fixed effect in the cow-level model for primiparous cows, and of borderline significance in the model for multiparous cows. Different random selections of one quarter per cow were analyzed to check robustness. The overall conclusion, however, regarding significance of the evaluated risk factors was unchanged (data not shown).

The disadvantage of randomly selecting one quarter per cow is the decrease in sample size. A further decrease in sample size was necessary to control the correlation between parity and teat shape (i.e., the risk factor analysis had to be done separately for primiparous and multiparous cows). The decrease in sample size could have affected the results of the model. On the other hand, risk factors with low $P$ values such as DevPMF or teat orifice remained unchanged when analyzed in different random quarter samples. The prevalence of acute lesions and scar tissue at the teat orifice was low, and only one quarter showed milk leakage. Consequently, we could not assess the effect of acute pathological lesions or scar tissue at the teat orifice on the quarter risk and on the cow risk for milk leakage.

As expected and reported for cows milked by an automatic milking system (Persson Waller et al., 2003), larger peak milk flow rates were associated with greater risks for milk leakage in primiparous and mul- tiparous cows. Peak milk flow is determined by size of the teat orifice, intramammary pressure, milk yield, vacuum applied during milking, and other characteristics of the milking machine (Blake and McDaniel, 1978). Greater vacuum pressure stretches the teat orifice. The vacuum and other milk machine characteristics are herd-specific and were not included as fixed effects in the analysis. Only $10 \%$ of the variation in the data was at the herd level, indicating that differences between herds must have been small compared with individual cow effects. From a practical point of view, cows with high peak flows are preferable because of their shorter milking duration. Based on our results showing a linear increase in the risk of milk leakage with increasing DevPMF, selection of cows with the greatest peak flow rate cannot be recommended without consideration of the resulting side effects of increased risk for mastitis and hygiene problems. Leaked milk may enhance bacterial growth in the bedding material, and thus increase the risk for environmental mastitis in herd mates.

In both primiparous and the multiparous cows, characteristics of the teat orifice were associated with the risk for milk leakage. In both groups, cows with teat canal protrusions were at greater risk for milk leakage than those having normal teat orifices (Tables 5 and 6) and all other teat orifice levels (results not shown). Diameter of the teat canal may be larger in cows with teat canal protrusions than in cows having normal teat orifices or in cows having teat-end callosity. Cows having teat canal protrusions also may have had less sphincter muscle tone before milking.

Days in milk were a significant risk factor for milk leakage in all cows with nearly identical estimated coefficients in both parity models. A linear association was detected between DIM and the risk for milk leakage, but it has to be considered that we had no information for cows between 101 and 249 DIM. An increase in DIM by $100 \mathrm{~d}$ corresponded to an odds ratio for milk leakage of 0.55 in primiparous cows and 0.60 in multiparous cows. This is in contrast to other observations (Persson Waller et al., 2003), in which no relationship was detected between stage of lactation and milk leakage. In their study, cows were observed at 2-h intervals in the barn, whereas in our study, cows were observed at the time of morning milking. Differences in intramammary pressure and udder filling may have decreased the risk for milk leakage during the course of lactation-intramammary baseline pressure before milking as well as the ejection pressure is greatest during the first 4 mo of lactation (Mayer et al., 1991; Bruckmaier and Hilger, 2001) and declines as lactation advances. As the intramammary pressure decreases, the degree of udder filling before milking 
also decreases. The smaller the degree of udder filling, the smaller the amount of milk stored in the teat cistern, which reduces the pressure on the teat sphincter before milking is initiated.

The DevMilk was not significant in the models for multiparous and primiparous cows. In multiparous cows, no evidence of a relationship between milk leakage and MeanResMilk was detected. But primiparous cows were at less risk for milk leakage at greater MeanResMilk. Depending on the intensity of milk leakage, the cisternal milk fraction of affected cows may have been reduced before milking. Consequently, the amount of milk harvested during milking may have been less. Higher-yielding primiparous cows might have had more udder storage capacity (and thus lower intramammary pressure) than low-yielding primiparous cows. Two morphological features may be important: size of the teat or gland cistern and size of the udder. In primiparous cows, the size of the cisternal fraction is smaller than that in multiparous cows. The cisternal fraction decreases during lactation, but the decrease is less in primiparous cows than in multiparous cows (Bruckmaier and Blum, 1998). In our study, primiparous cows with tiny udders tended to have greater risk for milk leakage (results not shown). Further investigation is necessary to enlighten this relationship.

Multiparous cows with short teats were at greater risk for milk leakage, whereas teat shape did not affect the risk of milk leakage in primiparous cows. This difference may have been due in part to the smaller sample size of primiparous cows. It is possible that teat shapes are not a relevant risk factor in primiparous cows because, in general, these cows had smaller and narrower teat canals than multiparous cows. In primiparous cows, teat length, and length and diameter of teat canals increased during the first months of lactation (McDonald, 1973), making it difficult to model the effect when only one observation within lactation was analyzed. In multiparous cows, short teats increased the risk for milk leakage compared with longer and thicker teats. Short teats may have had shorter teat canals, resulting in an impaired sphincter muscle function when intramammary pressure before milking is elevated. Cows having inverted or flat teat ends seem to have a greater diameter or a shorter teat canal that may be stretched wider when the intramammary pressure is elevated.

The proportion of the total variation explained in milk leakage at the herd level was similarly small in primiparous (10.8\%) and multiparous cows (10.4\%), relative to that at the cow level. This suggests that changes in management practices and other herd-level related factors might have small impacts on the risk for milk leakage.

\section{CONCLUSIONS}

Primiparous and multiparous cows with teat canal protrusion and large peak milk flow were at increased risk for milk leakage. To reduce the prevalence of cows leaking milk, breeding programs should consider risk factors to reduce milk leakage. In addition, screening of multiparous cows for short teats and inverted teat ends may be beneficial in evaluating the risk for milk leakage. Because most of the variation in results occurred at the cow level, assessment and selection of individual cows is necessary to reduce the occurrence of milk leakage in the herd.

\section{ACKNOWLEDGMENTS}

Financial support from the Stiftung Schleswig-Holsteinsche Landschaft is gratefully acknowledged. We thank the farmers for their cooperation in the study.

\section{REFERENCES}

Baxter, E. S., P. M. Clarke, F. H. Dodd, and A. S. Foot. 1950. Factors affecting the rate of machine milking. J. Dairy Res. 17:117-127.

Blake, R. W., and B. T. McDaniel. 1978. Relationships among rates of milk flow, machine time, udder conformation, and management aspects of milking efficiency: A review. J. Dairy Sci. 61:363-378.

Brown, H., and R. Prescott. 1999. Applied Mixed Models in Medicine. John Wiley and Sons, Ltd., Chichester, UK.

Bruckmaier, R. M., and J. W. Blum. 1998. Oxytocin release and milk removal in ruminants. J. Dairy Sci. 81:939-949.

Bruckmaier, R. M., and M. Hilger. 2001. Milk ejection in dairy cows at different degrees of udder filling. J. Dairy Res. 68:369-376.

Dohoo, I. R., E. Tillard, H. Stryhn, and B. Faye. 2001. The use of multilevel models to evaluate sources of variation in reproductive performance in dairy cattle in Reunion Island. Prev. Vet. Med. 50:127-144.

Elbers, A. R., J. D. Miltenburg, D. de Lange, A. P. Crauwels, H. W. Barkema, and Y. H. Schukken. 1998. Risk factors for clinical mastitis in a random sample of dairy herds from the southern part of The Netherlands. J. Dairy Sci. 81:420-426.

Enevoldsen, C., K. B. Elgaard, N. P. Jensen, K. H. Nielsen, H. K. Nørregaard, and J. S. Philipsen. 2000. Identification of interactions and non-linear effects, assessment of herd effects, and model validation in dairy herd health management context. Abstract ID 516 in Proceedings of International Society for Veterinary Epidemiology and Economics 9, Breckenridge, CO.

Klaas, I. C. 2000. Mastitis and herd health in 15 dairy farms in Schleswig-Holstein, Germany - A field study. Ph.D. Diss., Free Univ. of Berlin, Germany.

Littell, R. C., G. A. Milliken, W. W. Stroup, and R. D. Wolfinger. 1996. SAS System for Mixed Models. SAS Institute, Inc., Cary, NC.

Mayer, H., R. Bruckmaier, and D. Schams. 1991. Lactational changes in oxytocin release, intramammary pressure and milking characteristics in dairy cows. J. Dairy Res. 58:159-169.

McDonald, J. S. 1973. Radiographic method for anatomic study of the teat canal: Changes within the first lactation. Am. J. Vet. Res. 34:169-171. 
Nielsen, S. S., Y. T. Gröhn, and C. Enevoldsen. 2002. Variation of the milk antibody response to paratuberculosis in naturally infected dairy cows. J. Dairy Sci. 85:2795-2802.

Persson Waller, K., T. Westermark, T. Ekman, and K. SvennerstenSjaunja. 2003. Milk leakage - An increased risk in automatic milking systems. J. Dairy Sci. 86:3488-3497.

Rosenberger, G. 1979. Clinical Examination of Cattle. Verlag Paul Parey, Berlin and Hamburg, Germany.

Schukken, Y. H., F. J. Grommers, D. van de Geer, H. N. Erb, and A. Brand. 1990. Risk factors for clinical mastitis in herds with a low bulk milk somatic cell count. 1. Data and risk factors for all cases. J. Dairy Sci. 73:3463-3471.

Schukken, Y. H., F. J. Grommers, D. van de Geer, H. N. Erb, and A. Brand. 1991. Risk factors for clinical mastitis in herds with a low bulk milk somatic cell count. 2. Risk factors for Escherichia coli and Staphylococcus aureus. J. Dairy Sci. 74:826-832.

Sieber, R. L., and R. J. Farnsworth. 1981. Prevalence of chronic teatend lesions and their relationship to intramammary infection in 22 herds of dairy cattle. JAVMA 178:1263-1267.

Vandeputte-Van Messom, G., J. Bernabe, C. Burvenich, and G. Peeters. 1984. Effect of prazosin on the function of the teat sphincter in lactating cows. J. Dairy Res. 51:219-226.

Waage, S., S. A. Odegaard, A. Lund, S. Brattgjerd, and T. Rothe. 2001. Case-control study of risk factors for clinical mastitis in postpartum dairy heifers. J. Dairy Sci. 84:392-399.

Wendt, K., H. Bostedt, H. Mielke, and H. W. Fuchs. 1994. Euter-und Gesäugekrankheiten. Gustav Fischer Verlag, Jena, Germany. 